\title{
TRANSGENIC OIL PALM ANALYSIS VIA FLUORESCENCE in situ HYBRIDISATION, FLOW CYTOMETRY AND CYTOLOGICAL TECHNIQUES
}

MADON, M*; YAHAYA, I* and GHULAM KADIR AHMAD PARVEEZ*

\begin{abstract}
Transgenic oil palm plantlets containing the transgenes, phaA, phaB and phaC responsible for the synthesis of polyhydroxybutyrate (PHB) were analysed using flow cytometry (FCM), cytological and fluorescence in situ hybridisation (FISH). Flow cytometry analysis was carried out to determine the nuclear DNA content of the transgenic oil palm. Analysis of the results showed significant differences between all the transgenic events and DxP regenerated plantlets (control). The mean genome size for DxP regenerants $(2 \mathrm{C}=3.52 \pm$ $0.30 \mathrm{pg}$ ) was smaller compared with all the transgenic events, which had different genome sizes: TE 3-11 with size $2 \mathrm{C}=4.38 \pm 0.37 \mathrm{pg}, \mathrm{TE} 7-22$ with $2 \mathrm{C}=4.31 \pm 0.26 \mathrm{pg}, \mathrm{TE} 4-5$ with $2 \mathrm{C}=4.09 \pm 0.31 \mathrm{pg}, \mathrm{TE}$ 6-4 with $2 \mathrm{C}=4.07 \pm 0.63 \mathrm{pg}$, TE 9-4 with $2 \mathrm{C}=4.01 \pm 0.25 \mathrm{pg}$ and TE $11-15$ with $2 \mathrm{C}=4.01 \pm 0.37 \mathrm{pg}$. Cytological analysis showed no chromosomal aberrations such as anaphase bridges or lagging chromosomes. FISH analysis showed integration of transgenes on one or two chromosomes, targeting the distal region of long and middle length chromosomes.
\end{abstract}

Keywords: regenerants, polyhydroxybutyrate, transgenes, FISH, DNA content.

Date received: 10 April 2018; Sent for revision: 18 April 2018; Received in final form: 10 August 2018; Accepted: 15 August 2018.

\section{INTRODUCTION}

Genetic engineering is one of the modern alternative methods used to genetically improve a specific characteristic or trait of a plant using genes that could come from any living organisms, including non-sexual compatible plants species or even nonplant organisms such as bacteria and fungi. A single or multiple genes with known functions are stacked in an expression cassette or plasmid vector, introduced into the target plant genome through the genetic transformation process, and finally expressed (Gruber and Crosby, 1993). Among the most popular plant genetic transformation methods

Malaysian Palm Oil Board,

6 Persiaran Institusi, Bandar Baru Bangi,

43000 Kajang, Selangor, Malasysia.

E-mail: parveez@mpob.gov.my are biolistics (Sanford et al., 1987) and Agrobacterium tumefaciens-mediation (Fraley et al., 1983; Zambryski et al., 1983).

Commercial cultivation of oil palm in Malaysia began in 1917, and the planted area has grown to 5.81 million hectares in the year 2017. The industry has uplifted the nation's economy, and becoming one of the most significant contributors to Malaysia's gross domestic product (Kushairi et al., 2017). However, productivity needs to be further increased from 4-6 $t$ oil per hectare per year to $10 \mathrm{t}$ oil per hectare per year (Parveez et al., 2015a; Murphy, 2014) in order to address the demand of a growing world population and the limited arable land still available for planting. With the unveiling of the oil palm genome sequence and the coalition of the omics techniques, a foundation for a comprehensive and systematic crop improvement programme can be laid (Masura et al., 2017). Genetic engineering was identified as 
the most suitable approach to genetically modify oil palm for the following reasons: i) it can drastically reduce the time required for introgressing a desired trait; ii) the gene introgression is precise; and finally iii) it can broaden the genetic base of the palm as the source of genes can come from any biological sources (Sambanthamurthi et al., 2009). The main objective of genetic engineering in oil palm is to produce transgenic palms with increased monounsaturated oleic acid content (Parveez et al., 2015a). Other targeted products includes increasing the content of palmitoleic acid and of stearic acid, and synthesising biodegradable plastics, all of which are expected to boost the income of oil palm growers by producing high value products.

The production of transgenic oil palm that synthesises biodegradable plastics (polyhydroxybutyrate or PHB) was proposed because oil palm contains a high level of acetylCoA for fatty acid biosynthesis and a substrate for biodegradable plastic synthesis. PHB (the most common being polyhydroxyalkanoate or PHA) was first discovered in bacteria as a storage material under restricted growth conditions (Senior and Dawes, 1973). In 1980s, PHA was recognised for its thermoplastic and elastomeric properties (Poirier, 2002). Studies in the bacterial system showed that PHB is synthesised from acetyl-CoA through three enzymatic steps, namely, i) the production of 3-ketothiolase (phaA or bktB) that catalyses the reversible condensation of two acetyl-CoA moieties to form acetoacetyl-CoA, followed by ii) the production of acetoacetyl-CoA reductase (phaB) which than reduces the acetoacetyl-CoA to D-(-)-3-hydroxybutyryl-CoA, and finally iii) the polymerisation of D-(-)-3-hydroxybutyryl-CoA by PHB synthase (phaC) to synthesise PHB (Anderson and Dawes, 1990).

Research to regenerate transgenic oil palm was initiated in 1993 using particle bombardment or biolistics as it is the most effective method for transforming monocotyledonous plants like oil palm. This was achieved following extensive optimisation of the particle bombardment parameters; identification of the most effective selection agent for selecting transformants; determination of biological and physical parameters to maximise delivery of DNA into embryogenic calli; and finally selection of the strongest constitutive promoter to drive the transgene (Parveez et al., 2000). Besides particle bombardment, transformation of oil palm using Agrobacterium tumefaciens and protoplasts has also been reported (Masani et al., 2014; Masli et al., 2009). Plasmid pME22 (Willis et al., 2008), which carries all the PHB genes (phaA, phaB and phaC) isolated from the bacteria Ralstonia eutropha (Peoples and Sinskey, 1989a, b, c), and the bar gene isolated from Streptomyces hygroscopicus conferring resistance to the herbicide Basta or biolaphos (DeBlocket al., 1987), all driven by a maize polyubiquitin promoter and its intron (Christiensen et al., 1992), was transformed into oil palm using the biolistics method previously optimised for oil palm (Parveez et al., 2008).

The biolistics method, however, often generates very large, high-copy-number transgenic loci, usually around 1-20 transgene copies per locus (Pederson et al., 1997). The position of integration and the structure of transgene loci can vary considerably among independent transformants, and each of these factors may have a profound effect on the level and stability of transgene expression. Therefore, in order to ascertain the level of transgene integration in oil palm, various analyses at the genomic level were done. The analyses were genome size estimation of the control and transgenic regenerants via flow cytometry (FCM), cytological analysis to observe chromosomal aberrations, and finally fluorescence in situ hybridisation (FISH) using the plasmid vector as a probe to detect the presence of transgenes on the transgenic oil palm chromosomes.

FCM is a powerful technique because it is fast and efficient, and is widely used in genome size analysis of plant species (Midin et al., 2017). For example in wheat, using FCM of individual chromosomes or flow sorting, chromosomes that carry even single copy transgenes can be identified (Capal et al., 2016). However, for oil palm, flow sorting is not possible due to the similarity in chromosome size, particularly for chromosomes in groups 2 and 3 (Singh et al., 2013). The oil palm genome size has been estimated by Rival et al. (1997) using FCM, in an effort to compare the ploidy levels of oil palm tissue culture, seedlings and three different calli, and they reported the genome size to be $2 \mathrm{C}=3.76$ $\pm 0.09 \mathrm{pg}$ or $3.4 \times 10^{9} \mathrm{bp}$, with all the samples being diploid. On the other hand, Madon et al. (2008) who developed an FCM method to estimate the genome size of adult oil palm has reported the $2 \mathrm{C}$ DNA content of E. guineensis to be $3.86 \pm 0.26 \mathrm{pg}$. Transgene integration into plant genomes can have an impact on the size of the plant genome. Hence, in this study, the flow cytometry approach was adopted by which genome size comparisons were performed on control non-transgenic and transgenic regenerants.

The success in propagating oil palm via tissue culture and the ability to transform oil palm with foreign genes via particle bombardments have made genetic engineering a promising tool for improving the oil quality and for synthesising new products from the oil palm in order to sustain the industry. However, tissue culture calli frequently exhibit chromosomal aberrations such as bridging and lagging while transgenic materials exhibit chromosomal breakages (Lucia et al., 2011; Pederson et al., 1997). Therefore in this study, cytological analysis on metaphase chromosomes of Feulgenstained transgenic meristematic root tip cells 
was done to detect any possible chromosomal aberrations in transgenic oil palm.

The FISH technique is very effective for answering a broad range of genome-scale questions (Findley et al., 2017). FISH has been used on maize to distinguish chromosomes of different accessions, to map single genes, to locate transposable elements and transgene insertions, and to identify chromosomal alterations (McCaw et al., 2016). In several plant species, FISH was used to visually locate the transgene integration sites which can then lead to studies on transgene activity (Svitashev and Somers, 2002; Jakowitsch et al., 1999). Most of these studies focused on the use of metaphase chromosomes for which determination of the integration sites on chromosomes is easier as reported for tobacco, wheat, barley, cotton and rice (Rahman et al., 2010; Park et al., 2010; Harwood et al., 2005; Salvo-Garrido et al 2004; Choi et al., 2002; Abranches et al., 2000; Iglesias et al., 1997). However, FISH has also been conducted on interphase nuclei where transgene expressions have been reported to occur (Santos et al., 2006). For non-plant species, FISH has been used to detect transgenes in Drosophila, Dictyostelium discoideum (a soil-living amoeba), Cyprinus carpio (carp fish) and mice (Abramov et al., 2016; Chen et al., 2015; Windohf et al., 2013; McHugh et al., 2012). Hence, in this study, the identification of the locations of the transgenes was also analysed by FISH.

\section{MATERIALS AND METHODS}

\section{Plant Materials and Methods of Analyses}

Six transgenic oil palm events (namely, TE 3-11, TE 4-5, TE 6-4, TE 7-22, TE 9-4 and TE 11-15) carrying the PHB genes were used in the study. The transgenic oil palms were produced after particle bombardment of oil palm embryogenic callus with the plasmid pME22, which carries three PHB genes (phaA, phaB and phaC) and the bar gene for resistance to the herbicide Basta, driven by a maize polyubiquitin promoter as reported earlier (Parveez et al., 2008). For each of the six transgenic events, three independent plantlets were selected and were analysed by FCM, cytological study and FISH, using the pME22 plasmid as a probe. Controls used were DxP seedlings and tissue culture regenerants. The first fully opened leaves were used for genome estimation via FCM while root tip meristems were used for cytological and FISH analyses.

\section{Estimation of Genome Size by FCM}

Nuclei preparation for FCM analysis. For nuclei preparation, leaf samples of about $1 \mathrm{~cm} \times 1 \mathrm{~cm}$ were taken from the basal, middle and distal regions of the youngest opened leaf. Samples per leaflet were combined and sliced into smaller pieces using clean sharp blades. The sliced fresh leaf materials were placed into a 50- $\mu \mathrm{m}$ Medicon blender container (Becton Dickinson, USA) holding $1 \mathrm{ml}$ of lysis buffer LBO1 supplemented with $50 \mu \mathrm{g}$ of propidium iodide (GIBCO BRL, USA) and $50 \mu \mathrm{g}$ of RNaseA, and blended for 3-5 min. The suspended nuclei were then collected from the blender using a 1-ml syringe, and filtered through a $70-\mu \mathrm{m}$ sieve (Becton Dickinson, USA) into a 10-ml falcon tube, and stored at $4^{\circ} \mathrm{C}$ for $48 \mathrm{hr}$ prior to FCM analysis.

Determination of genome size. A FACS Calibur flow cytometer (Becton Dickinson, USA) equipped with an argon ion laser $(15 \mathrm{~mW})$ at $448 \mathrm{~nm}$ was used to analyse the fluorescence intensity of the nuclei samples. A histogram was constructed over 1024 channels, and for each sample, 25000 events were captured. The values of oil palm and soyabean histogram peak means were obtained using Cell Quest software. Using these values, 2C genome size was calculated from the ratio of oil palm to soyabean fluorescence intensity, multiplied by $2.5 \mathrm{pg}$, i.e. the genome size of soyabean.

The formula used to calculate $2 \mathrm{C}$ genome size of the control and transgenic regenerants with soyabean (Glycine max cv. Polanka, $2 \mathrm{C}=2.5 \mathrm{pg}$ ) as an external reference standard is:

$$
2 \mathrm{C} \text { Elaeis DNA }=\frac{\begin{array}{c}
2 \mathrm{C} \text { soyabean DNA } \mathrm{x} \text { mean of } \\
\text { Elaeis DNA pg }
\end{array}}{\text { Mean of soyabean DNA }}
$$

Three replicates were used for each sample.

Statistical analysis. A one-way analysis of variance (ANOVA) and Tukey's test were performed to determine any significant difference among the different samples.

\section{Cytological Analysis of Transgenic Root tips}

Transgenic oil palm root tips were fixed in a formalin-acetic acid-alcohol (FAA) fixative at room temperature, kept overnight, and finally stored in $70 \%$ ethanol at $4^{\circ} \mathrm{C}$. When needed, the root tips were rinsed in distilled water, and acid-hydrolysed in $1 \mathrm{~N}$ $\mathrm{HCl}$ at $60^{\circ} \mathrm{C}$ for $12 \mathrm{~min}$. $\mathrm{HCl}$ was dispensed before addition of $1 \mathrm{ml}$ Feulgen stain, followed by a 45 min incubation period at room temperature. Stained merismetic root tips were dissected in a drop of $45 \%$ acetic acid. The tissues were squashed, large debris removed, coverslips laid on the samples, and thumb pressure applied to spread out the cells. The slides were then frozen in liquid nitrogen vapour, coverslips removed, and air-dried overnight. On the next day, the slides were dehydrated in ethanol series, followed by immersion in xylene, mounted 
with Canadian Balsam, and air-dried overnight. Microscopy observations were done using a Zeiss Axioplan microscope at 40X magnification, and images were captured and analysed using a Leica 100 camera and Leica Imaging Software.

\section{FISH of pME22}

Transgenic oil palm root tips were fixed in $2 \mathrm{mM}$ 8-hydroxyquinoline for $5-6 \mathrm{hr}$ at $18^{\circ} \mathrm{C}$ to maximise the metaphase index. The root tips were then rinsed several times with distilled water, fixed with Carnoy's fixative overnight at $4^{\circ} \mathrm{C}$, followed again by rinsing with distilled water, and stored in 70\% ethanol at $4^{\circ} \mathrm{C}$. When needed, the root tips were rinsed in distilled water, the meristems dissected and digested with $20 \%$ cellulase-pectinase for 2-3 $\mathrm{hr}$ at $37^{\circ} \mathrm{C}$. Each root tip meristem was then placed on a microscope slide with a drop of $60 \%$ acetic acid, followed by squashing using a steel rod. Large debris were removed using a pair of fine forceps, and a coverslip was laid on the suspension. A few pieces of filter papers were placed on the coverslip, followed by gentle tapping with the steel rod, and finally thumb pressure was applied to spread the cells. The slides were screened for quality, followed by freezing in liquid nitrogen vapour. The coverslips were removed, and the slides dehydrated in ethanol series and air-dried overnight.

The probe pME22 (a fragment consisting of phaB, $b k t B$ and $p h a C$ genes) is derived from the plasmid (Willis et al., 2008) used in the transformation

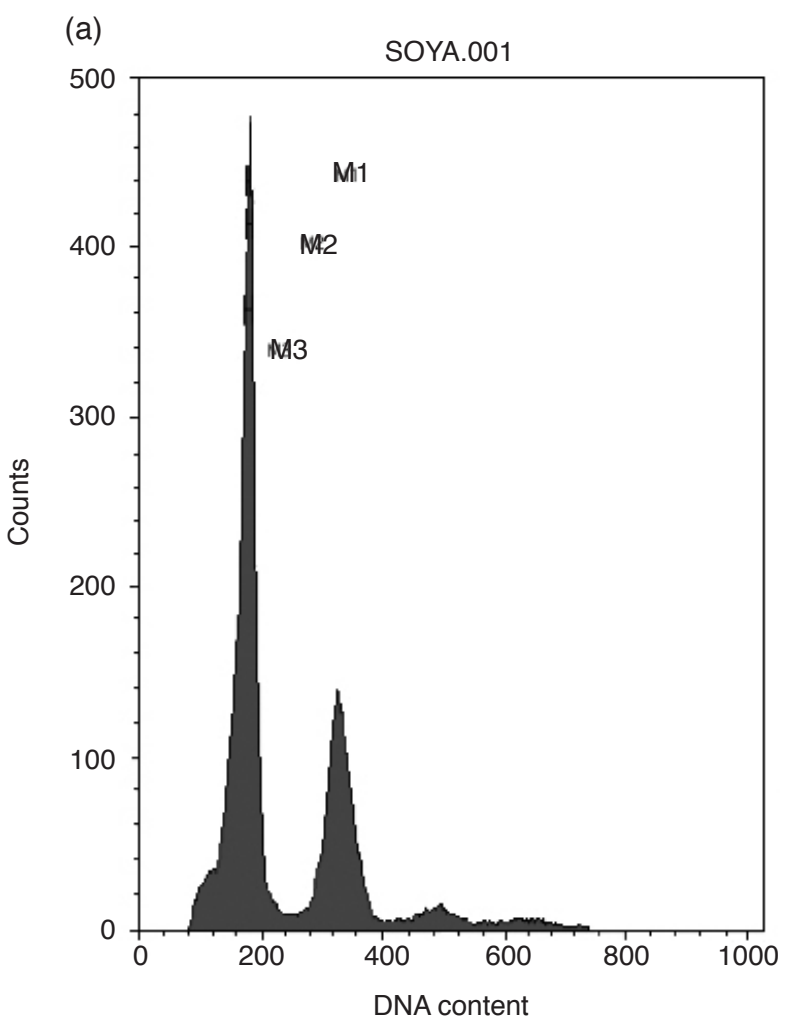

work. The probe was labelled with Biotin-14-dCTP (Bioprime Labelling System), according to the manufacturer's protocol. FISH experiments were done according to the method by Schwarzacher et al. (1989), except that an additional amplification with biotinylated-avidin was added to provide stronger transgenes signals if present in the genome. After the last detection step with FITC-avidin, the slides were incubated in biotynilated-avidin for 1 $\mathrm{hr}$, then again followed by incubation with FITCavidin. Next, the slides were rinsed and mounted with KPL anti-fluorescence media before being covered by coverslips, while any excess media was removed with filter paper. Microscopy visualisation and image analysis were done using a Leica QF 550 workstation at $63 \mathrm{X}$ magnification.

\section{RESULTS AND DISCUSSION}

\section{Estimation of 2C Nuclear Genome Size}

In this study, a total of 25000 palm nuclei were measured to lower the percentage of error caused by variation $(\mathrm{CV})$ of the $2 \mathrm{C}$ histogram peaks which occurs at the G0/G1 phase of the cell cycle. Figure 1 shows sharp fluorescence intensity histogram peaks for the external reference standard Glycine max cv Palmetto and E. guineensis DxP regenerants. This indicates that the nuclei isolated were intact and the DNA was well-stained with the intercalating dye propidium iodide (PI). Table 1 shows the $2 \mathrm{C}$ values

(b)

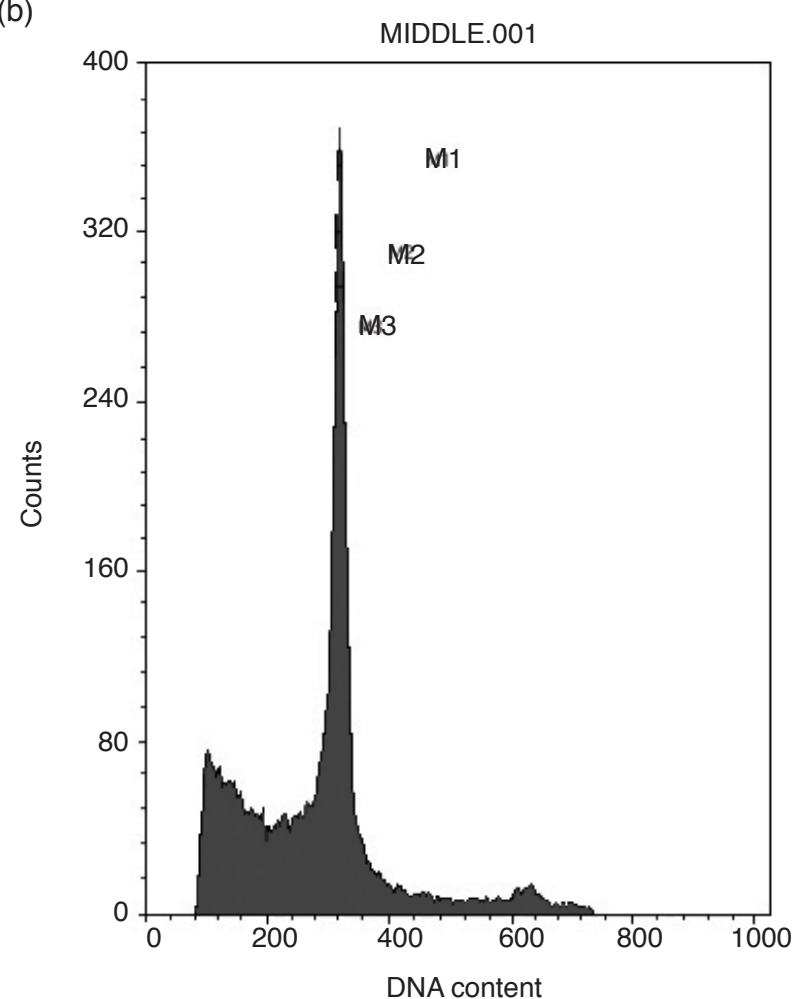

Figure 1. Fluorescence intensity histogram peak of (a) external reference standard Glycine max cv Palmetto and (b) E. guineensis (tenera, DxP). 
TABLE 1. ONE-WAY ANALYSIS OF VARIANCE ON THE 2C GENOME SIZE OF THE DxP REGENERANTS AND TRANSGENIC EVENTS (individual 95\% CI for mean based on pooled standard deviation)

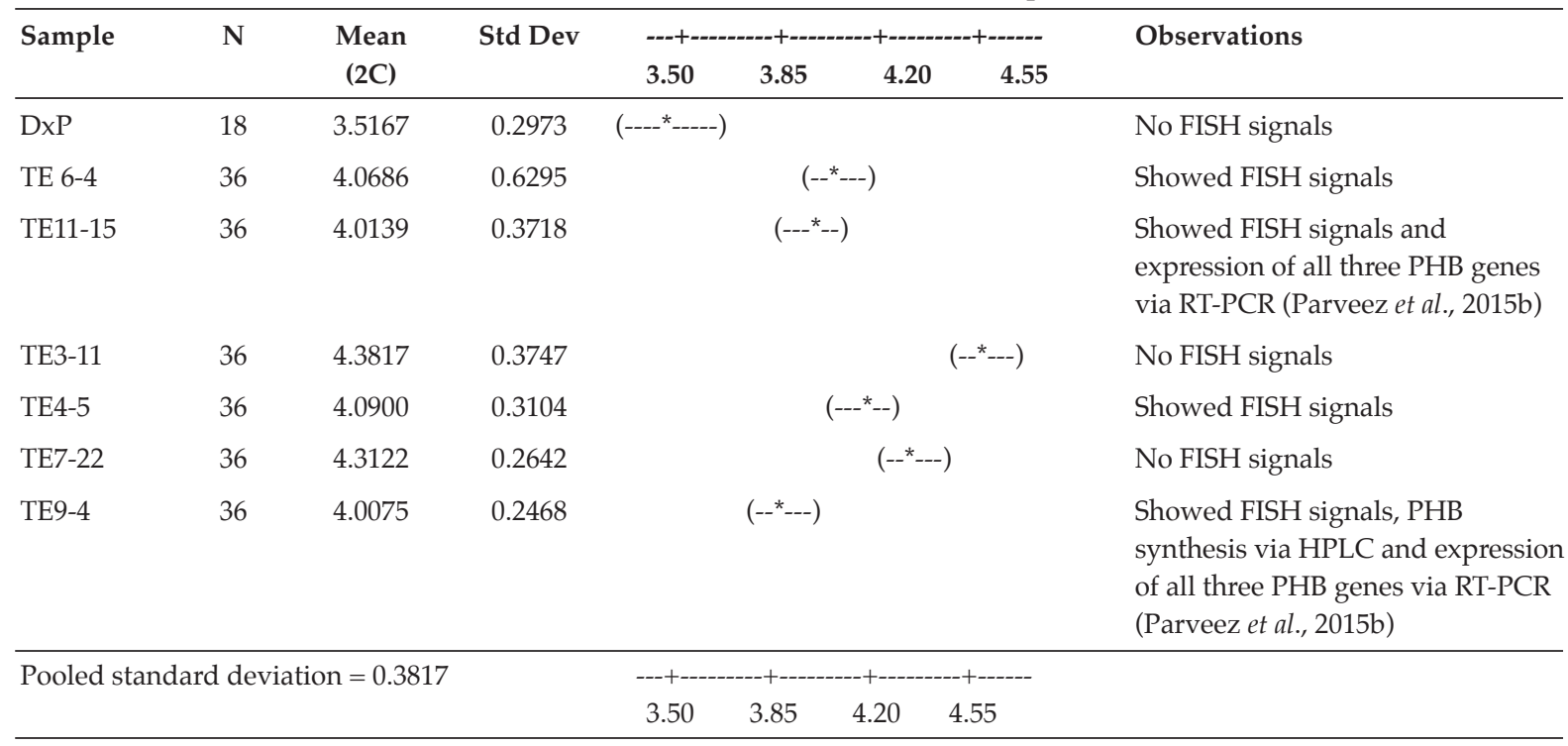

Note: FISH - flourescene in situ hybridisation.

PHB - polyhydroxybutyrate.

HPLC - high performance liquid chromatography.

RT-PCR - reverse transcription-polymerase chain reaction.

of the DxP regenerants (non-transgenic) and the average genome size of the three plantlets from the respective chosen transgenic events and the oneway analysis of variance (ANOVA) between the DxP regenerants (non-transgenic) and the six transgenic events. The $2 \mathrm{C}$ DNA content of the DxP regenerants was significantly different from the DNA contents of the set of transgenic oil palm events. Particle bombardment often generates very large, highcopy-number transgenic loci and there are usually 1-20 transgene copies per locus, and the position of integration and the structure of the transgene loci also can vary considerably among independent transformants (Pederson et al., 1997).

From this study, it was observed that there were significant differences between the DxP regenerants and all the transgenic events, and this might indicate multicopies of the transgenes insertions. The $2 \mathrm{C}$ nuclear genome size of all the transgenic events were larger than that of the non-transgenic DxP regenerants (Table 1). The variation can also be due to endopolyploidy, polyploidisation, uneven chiasmata, transposition, duplication in gene locus, an increase in potential gene products with several gene functions, as well as changes in the nucleosomes structure (Kubis et al., 1998).

The observations on genome size of the six transgenic oil palm events showed that TE 6-4, TE 11-15, TE 4-5 and TE 9-4 exhibited no significant difference among them, however, the four events demonstrated significant differences when compared with TE 3-11 and TE 7-22 which have larger genome size. On the other hand, the transgenic events TE 9-4 and TE 11-15 had the smallest genome size of $2 \mathrm{C}=4.0075 \pm 0.2468$ and $2 \mathrm{C}=4.0139 \pm 0.3718$, respectively, compared with the other four events. A higher number of transgene insertions may have caused PHB transgene silencing in the four events, TE 6-4, TE 4-5, TE 3-11 and TE 7-22, as reported earlier where only two transgenic events (TE 9-4 and TE 11-15) showed either the synthesis of PHB based on high performance liquid chromatography (HPLC) analysis and/or PHB genes expression based on RT-PCR (Parveez et al., 2015b).

\section{Cytological Analysis of Transgenic Oil Palm}

A plant transformation process involves a series of steps in which DNA must be introduced into a single cell, multiplied in vitro during the selection process and result in transformed plants. Chromosomal aberration is often observed during tissue culture and the transformation process, and reportedly also contributes to the instability of transgene expression (Choi et al., 2002). Imperfections during the folding of single fibre chromatids of chromosomes cause chromosomes to become attached to each other by a subchromatid bridge. During the anaphase stage, features such as anaphase bridges can be observed. Under more chronic conditions, the chromosomes do not separate during anaphase and when the bridge is destroyed, chromosomal aberrations will result (Rayburn and Wetzel, 2002). Lucia et al. (2011) 
showed an example of an anaphase bridge and a lagging chromosome in oil palm callus. Cytological analyses of transgenic oil palm plants are carried out to detect any chromosomal aberrations. The results of the cytological screening of 540 cells ( 30 cells per slide for each palm; three palms per event for six events) of the transgenic oil palm root tip meristematic nuclei spreads show no anaphase bridge or the phenomenon of lagging chromosomes, however, this does not rule out other aberrations such as translocation or chromosomal breakages. Figures $2 a$ and $2 b$ show normal anaphase nuclei and the absence of lagging chromosomes.

\section{Localisation of PHB Transgenes on Chromosomes via FISH pME22 Probe}

FISH analysis on chromosomes of the six independent transgenic oil palm events showed that PHB transgene integration in the oil palm genome mostly occurred at distal region of at least one chromosome pair. In Figures $3 a$ and $3 b$, the metaphase chromosomes of the untransformed DxP regenerants which served as the control did not show any transgenes signal, while in Figures $3 c$ to $3 l$, one or two transgenes signals were observed on the distal telomeric regions of at least one or two chromosomes of TE 6-4, TE 11-15, TE 4-5 and TE 9-4. TE 3-11 and TE 7-22 did not exhibit any transgenes FISH signals. This may be due to the truncated insertion of transgenes which caused the probe pME 22 to be unable to hybridise with the transgenes, hence a failure to exhibit FISH signals. Table 1 shows the overall observations from the analysis conducted for this study. Parveez et al. (2015b) reported that PCR analysis on all the six transgenic oil palm events showed that they have the PHB genes integrated into their genome. However, only two transgenic events, namely, TE 9-4 showed expression of all the PHB genes using RT-PCR and the synthesis of the PHB using HPLC, and TE 11-15 showed expression of all the PHB genes using RTPCR only. The FISH results supported the presence of transgenes in TE 9-4 and TE 11-15; however, for TE 6-4 and TE 4-5, even though FISH signals were present, the expression of the transgenes was not detected via RT-PCR nor was synthesis detected via HPLC (Parveez et al., 2015b). TE 6-4 and TE 4-5 had higher DNA content than TE 9-4 and TE $11-15$, and this may have caused the transgenes to be detected via FISH while the PHB transgenes may have been silenced, resulting in failure to exhibit transgenes expression or synthesising PHB. Insertion of multiple copies of transgenes either on the same chromosome or on different chromosomes can lead to homology-dependent gene silencing (HDGS) which can silence the transgene or render it ineffective, as demonstrated in tobacco and Arabidopsis (Davies et al., 1997; Matzke et al., 1989). Transgene expression also depends on several other factors such as the location of the transgene, the level of DNA methylation, position accuracy and restructuring of the transgene in chromosomes, and also the transgene copy number (Stam et al., 1997).

FISH analysis on transgenic hexaploid oat which contains ACD genomes showed that the genomes of A / D and C as well as other chromosomes are likely to accept foreign DNA integration as well (Svitashev et al., 2000). However, such integration is more prone to the gene-rich portion of the telomere and subtelomer of the transgenic oat chromosomes, and this is similar to oil palm transgenic chromosomes. For transgenic oats, 18 of the 26 transgene inserts were detected at the telomere and subtelomer regions. The distal parts normally consist of euchromatin which is a transcriptionally active form
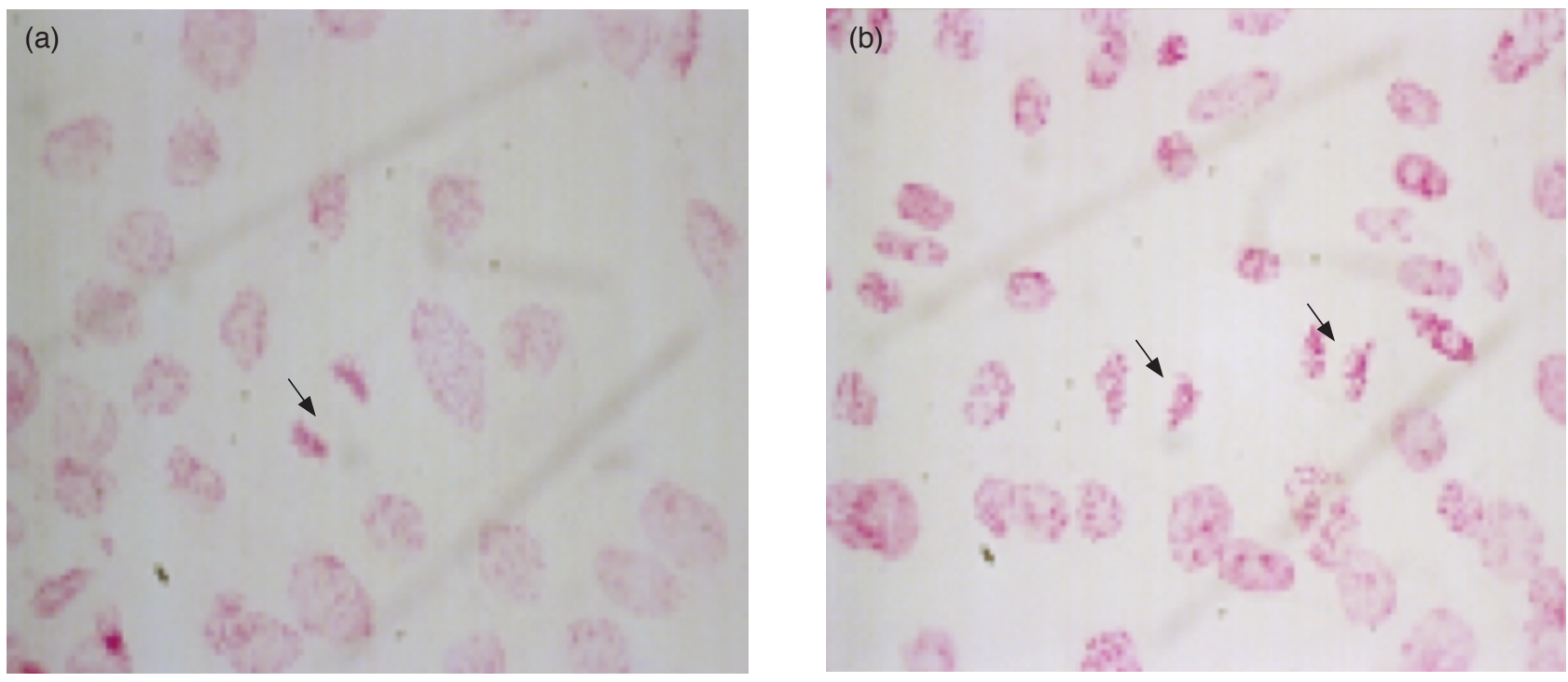

Figure 2. (a) and (b) show normal anaphase nuclei (arrow) without any bridging and lagging chromosome. 


\begin{tabular}{lll}
\hline Plant sample & & Results of FISH analy \\
\hline $\begin{array}{l}\text { DxP } \\
\text { seedling }\end{array}$ & $\begin{array}{l}\text { (a) No transgene } \\
\text { signals were } \\
\text { (control) }\end{array}$ & $\begin{array}{l}\text { detected } \\
\text { s. }\end{array}$
\end{tabular}

\begin{tabular}{ll}
\hline TE11-15 & (c) Transgene \\
& signals (arrow) \\
& were detected \\
on two \\
chromosomes
\end{tabular}

(b) No transgene signals were detected

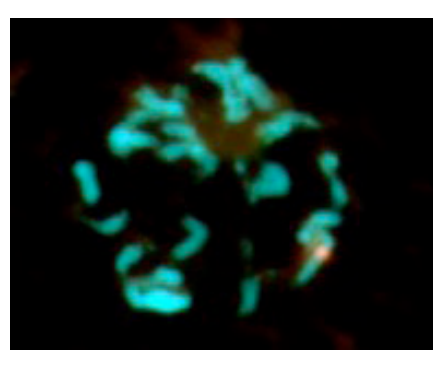

\begin{tabular}{ll}
\hline TE6-4 & (e) Transgene \\
& signals (arrows) \\
& were detected \\
on two \\
chromosomes
\end{tabular}

(d) Transgene signal (arrow) was detected on one chromosome

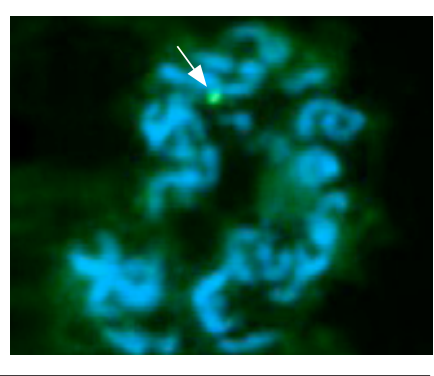

(f) Transgene signals (arrows) were detected on two chromosomes

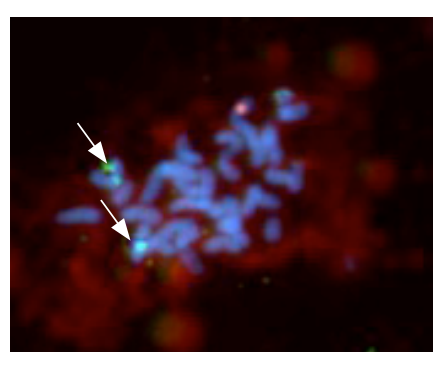

\section{TE9-4}

(g) Transgene signals (arrows) were detected on two chromosomes

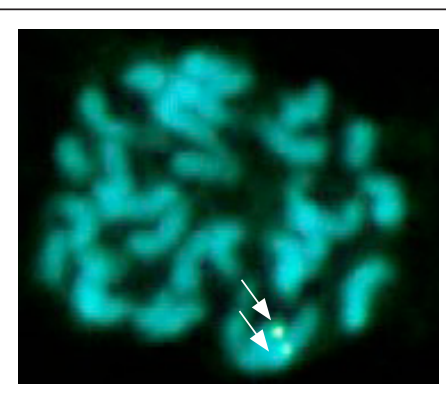

(h) Transgene signals (arrows) were detected on two chromosomes

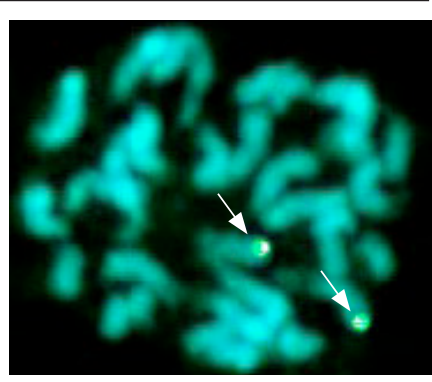

(i) Transgene signals (arrows) were detected on two chromosomes

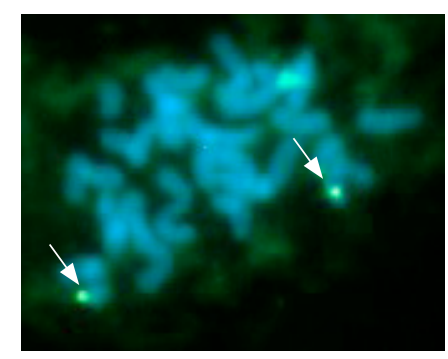

(j) Transgene signals (arrows) were detected on two chromosomes

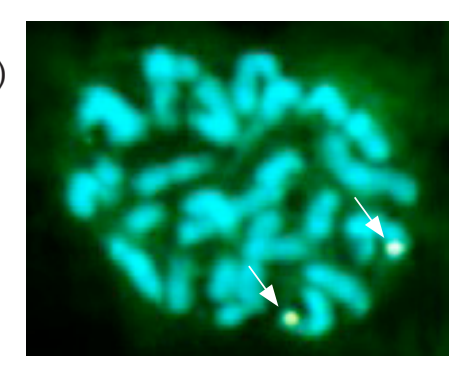

\section{TE4-5}

(k) Transgene signals (arrows) were detected on two chromosomes

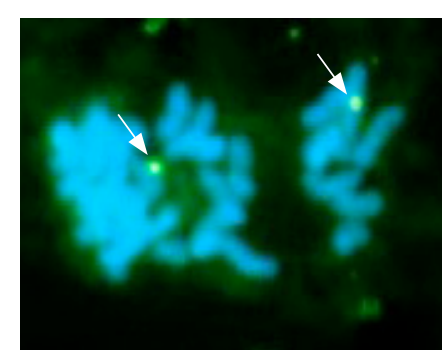

(I) Transgene signals (arrows) were detected on two chromosomes

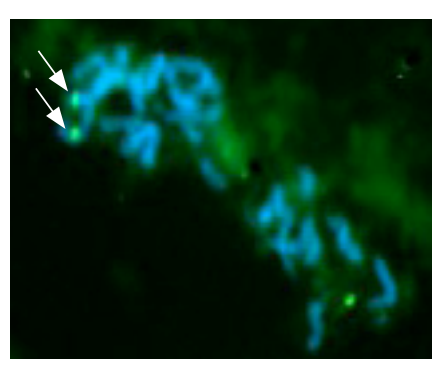

Figure 3. Florescence in situ hybridisation (FISH) analysis of pME22 ( $a$ and $b$ ) non-transgenic DxP seedlings showed no transgene signals and ( $c-l$ ) transgenic oil palm showed transgene signals (arrows) on one or two chromosomes. 
of chromatin, and contain a large number of actively transcribed genes, hence, the region would be more susceptible to transgenes integration (Pederson et al., 1997). These distal transgenes integrations may show high or stable activities, whereas activity of alien genes integrated near the centromeric regions is low or unstable due to the presence of more heterochromatin in the centromeric regions (Iglesias et al., 1997). The physical position of the transgene has been identified by FISH analysis for grain crops such as barley, wheat, oats and triticale (Choi et al., 2002; Salvo-Garrido et al., 2001; Svitashev et al., 2000; Pederson et al., 1997).

FISH analysis is fast, safe, and able to combine several probes in a single experiment, making it the method of choice for gene mapping studies (Joos et al., 1994). However, FISH analysis on plant chromosomes is more challenging than on animal chromosomes due to the presence of cell walls and cytoplasm which prevents chromosomes from being well-dispersed.

\section{CONCLUSION}

The use of flow cytometry, cytological and FISH analyses in this study has assisted in the understanding of the effect of the insertion of transgenes in the oil palm genome using the biolistics transformation method. Using flow cytometry, significant genome size differences can be observed between the DxP regenerants and the transgenic events, with all the transgenic plantlets showing larger genome size than the non-transgenic. This indicates that the increase may be due to multiple copies of the transgene being inserted during the biolistics transformation process. Cytological analysis did not exhibit any anaphase bridges or chromosome lagging. Chromosome breakages are quite difficult to observe due to the small sized chromosomes. FISH analysis showed transgenes signals on one or two chromosomes of four out of the six transgenic events studied. As this is the first report on the detection of transgenes in oil palm cells using genomic-level tools, it can be concluded that these tools may be used to analyse future transgenic events to compare them with non-transgenic regenerants.

\section{ACKNOWLEDGEMENT}

The authors thank the Director-General of MPOB for permission to publish this article. This research was funded initially by the government of Malaysia through the Ministry of Science, Technology and Invention under the Malaysia-MIT Biotechnology Partnership Programme (MMBPP) and later by MPOB.

\section{REFERENCES}

ABRAMOV, Y A;SHATSKIKH, AS; MAKSIMENKO, O G; BONACCORSI, S; GVOZDEV, V A and LAVROV, SA (2016). The differences between cis- and trans-gene inactivation caused by heterochromatin in Drosophila. Genetics, 202: 93-106.

ABRANCHES, R; SANTOS, A P; WEGEL, E; WILLIAMS, S; CASTILHO, A; CHRISTOU, P; SHAW, P and STOGER, E (2000). Widely separated multiple transgene integration sites in wheat chromosomes are brought together at interphase. The Plant J., 24: 713-723.

ANDERSON, A J and DAWES, E A (1990). Occurrence, metabolism, metabolic role, and industrial uses of bacterial polyhyroxyalkanoates. Microbiology Review, 54: 450-472.

CAPAL, P; ENDO, T R; VRANA, J; KUBALAKOVA, M; KARAFIATOVA, M; KOMINKOVA, E; MORARAMIREZ, I; WESCHKE, W and DOLEZEL, J (2016). The utility of flow sorting to identify chromosomes carrying a single copy transgene in wheat. Plant Method, 12: 24-30.

CHOI, H W; LEMAUX, P G and CHO, M J (2002). Use of fluorescence in situ hybridization for gross mapping of trangenes and screening for homologous plants in transgenic barley (Hordeum vulgare L.). Theor. Appl. Genet., 106: 92-100.

CHRISTIENSEN, A H; SHARROCK, $\mathrm{R} \mathrm{A}$ and QUAIL, P H (1992). Maize polyubiquitine genes: Thermal perturbation of expression and transcript splicing, and promoter activity following transfer to protoplast by electroporation. Plant Molecular Biology, 18: 675-689.

DAVIES, G J; SHEIKH, M A; RATCHLIFFE, O J; COUPLANT, G and FURNER, I J (1997). Genetics of homology dependent gene silencing in Arabidopsis: A role for methylation. Plant J., 12: 971-804.

DeBLOCK, M; BOTTERMAN, J; VANDERWIELE, M; MONTAGU, $\mathrm{M}$ and LEEMANS, J (1987). Engineering herbicide resistant in plants by expression of a detoxifying enzyme. $E M B O \mathrm{~J} ., 6$ : 2513-2518.

FINDLEY, S D; BIRCHLER, J A and STACEY, G (2017). Fluorescence in situ hybridization for Glycine max metaphase chromosomes. Curr. Protoc. Plant. Biol., 2: 89-107.

FRALEY, R T; ROGERS, S G; HORSCH, R B; SANDERS, P R and FLICK, J S (1983) Expression of bacterial genes in plant cell. Proc. Natl. Acad. Sci. USA, 80: 4803-4807. 
GRUBER, M Y and CROSBY, W L (1993). Vectors for plant transformation. Methods in Plant Molecular Biology and Biotechnology (Glick, B R and Thompson, J E eds.). Boca Raton: CRC Press. p. 89-119.

HARWOOD, W A; BILHAM, L J; TRAVELLA, S; SALVO-GARRIDO, $\mathrm{H}$ and SNAPE, J W (2005). Fluorescence in situ hybridization to localize transgenes in plant chromosomes. Methods Mol Biol., 286: $327-340$

IGLESIAS, V; MOSCONE, E; PAPP, I; NEUHUBER, F; MICHALOWSKI, $S$ and PHELAN, T (1997). Molecular and cytogenetic analysis of stably and unstably expressed transgene loci in tobacco. The Plant Cell, 9: 1251-1264.

JAKOWITSCH, J; PAPP, I; MOSCONE, E.A; WINDEN, J V; MATZKE, M and MATZKE, A J M (1999). Molecular and cytogenetic characterization of a transgene locus that induces silencing and methylation of homologous promoters in trans. The Plant J., 17: 131-140.

JOOS, S; FINK, T M; RATSCH, A and LICHTER, $P$ (1994). Mapping and chromosome analysis. The potential of fluorescent in situ hybridization. J. Biotechnol., 35: 135-153.

KUBIS, S; SCHMIDT, T and HESLOP-HARRISON, J S (1998). Repetitive DNA elements as a major component of plants genomes. Ann. Bot., 82: 45-55.

KUSHAIRI, A; SINGH, R and ONG-ABDULLAH, M (2017). The oil palm industry in Malaysia: Thriving with transformative technologies. J. Oil Palm Res. Vol. 29(4): 431-439.

LUCIA, G; CASTIGLIONE, M R; TURRINI, A; RONCHI, V N and GERI, C (2011). Cytogenetic and histological approach for early detection of 'mantled' somaclonal variants of oil palm regenerated by somatic embryogenesis: First results on the characterization of regeneration system. Caryologia, 64(2): 221-232.

MADON, M; PHOON, L Q; CLYDE, M M and MOHD, D A (2008). Application of flow cytometry for estimation of nuclear DNA content in Elaies. J. Oil Palm Res. Vol. 20: 447-452.

MASANI, M Y A; NOLL, G; PARVEEZ, G K A; SAMBANTHAMURTHI, R and PRUEFER, D (2014). Efficient transformation of oil palm protoplasts by PEG-mediated transfection and DNA microinjection. PLoS ONE, 9(5): e96831. DOI:10.1371/journal. pone.0096831.

MASLI, D I A; PARVEEZ, G K A and YUNUS, A M M (2009). Transformation of oil palm using
Agrobacterium tumefaciens. J. Oil Palm Res. Vol. 21: 643-652.

MASURA, S S; TAHIR, N I; RASID, O A; RAMLI, U S; OTHMAN, A: MASANI, M Y A; PARVEEZ, G K A and KUSHAIRI, A(2017). Post-genomic technologies for the advancement of oil palm research. J. Oil Palm Res. Vol. 29(4): 469-486.

MATZKE, M A; PRIMIG, M; TRANOVSKY, J and MATZKE, A J M (1989). Reversible methylation and inactivation of marker genes in sequentially transformed tobacco plants. EMBO J., 7: 643-649.

McCAW, M; GRAHAM, N; CODY, J; SWYERS, N; ZHAO, C and BIRCHLER, J (2016). Fluorescence in situ hybridization to maize (Zea mays) chromosomes. Curr. Protoc. Plant. Biol., 1: 530-545.

McHUGH, D; O'CONNOR, T; BREMER, J and AGUZZI, A (2012). ZyFISH: A simple, rapid and reliable zygosity assay for transgenic mice. PLoS ONE, 7(5): e37881. https:/ / doi.org/10.1371/journal. pone.0037881

MIDIN, M R; NORDIN, M S; MADON, M; SALEH, M N; GOH, H H and MOHD NOOR, N (2017). Determination of the chromosome number and genome size of Garcinia mangostana L. via cytogenetics, flow cytometry and k-mer analyses. Caryologia. DOI: 10.1080/00087114.2017.1403762

MURPHY, D J (2014). The future of oil palm as a major global crop: Opportunities and challenges. J. Oil Palm Res. Vol. 26: 1-24.

PARVEEZ, G K A; RAID, O; ZAINAL, A; MASRI, M M; MAJID, N A; FADILLAH, H H; YUNUS, A M M and CHEAH, S C (2000). Transgenic oil palm: Production and projection. Biochemistry Society Transactions 28: 969-972.

PARVEEZ, G K A; BAHARIAH, B; AYUB, N $\mathrm{H}$; MASANI, M Y A; RASID, O A; HASHIM, A T; ISHAK, Z; MANAF, M A A; DIN, A K; YORK, G; YEONG, B J and SINSKEY, A J (2008). Transformation of $\mathrm{PHB}$ and $\mathrm{PHBV}$ genes driven by maize ubiquitin promoter into oil palm for the production of biodegradable plastics. J Oil Palm Res. Special Issue July 2018: 77-86.

PARVEEZ, GKA; RASID, O A; MASANI, MY A and SAMBANTHAMURTHI, R (2015a). Biotechnology of oil palm: Strategies towards manipulation of lipid content and composition. Plant Cell Reports, 34: 533-543.

PARVEEZ, G K A; BAHARIAH, B; AYUB, N H; MASANI, M Y A; RASID, O A; TARMIZI, A $\mathrm{H}$ and ISHAK, Z (2015b). Production of 
polyhydroxybutyrate in oil palm (Elaeis guineensis Jacq.) mediated by microprojectile bombardment of PHB biosynthesis genes into embryogenic calli. Front. Plant Sci., 6: 598. DOI: 10.3389 / fpls.2015.00598

PARK, H M; JEON, E J; WAMINAL, N E; SHIN, K S; KWEON, S J; PARK, B S; SUH, S C and KIM, $\mathrm{H} \mathrm{H}$ (2010). Detection of transgenes in three genetically modified rice lines by fluorescence in situ hybridization. Genes \& Genomics, 32: 527-531.

PEDERSEN, C; ZIMNY, J; BECKER, D; JANHNEGARTNER, A and LORZ, H (1997). Localization of introduced genes on the chromosomes of transgenic barley, wheat and triticale by fluorescence in situ hybridization. Theor. Appl. Genet. 94: 749-757.

PEOPLES, O P and SINSKEY, A J (1989a). Poly- $\beta$ hydroxybutyrate (PHB) biosynthesis in Alcaligenes eutrophus H16. Characterization of the genes encoding $\beta$-ketothiolase and acetoacetyl-CoA reductase. J. Biological Chemistry, 264: 15293-15297.

PEOPLES, O P and SINSKEY, A J (1989b). Poly- $\beta$ hydroxybutyrate (PHB) biosynthesis in Alcaligenes eutrophus H16. Identification and characterization of the PHB polymerase gene (phbC). J. Biological Chemistry, 264: 15298-15303.

PEOPLES, O P and SINSKEY, A J (1989c). International patent, WO 89/ 00202.

POIRIER, Y (2002). Polyhydroxyalkanoate synthesis in plants as tool for biotechnology and basic studies of lipid metabolism. Progress Lipid Research, 41: 131155.

RAHMAN M; NOREEN, S; HUSNAIN, T and RIAZUDDIN, S (2010). A fast and efficient method to determine the position of alien genes in transgenic plants. Emir. J. Food Agric., 22 (3): 223-231.

RAYBURN, A L and WETZEL, J B (2002). Flow cytometric analyses of intraplant nuclear DNA content variation induced by sticky chromosomes. Cytometry, 49: 36-41.

RIVAL, A; BEULE, T; BARRE, P; HAMON, S; DUVAL, Y and NOIROT, M (1997). Comparative flow cytometric estimation of nuclear DNA content in oil palm (Elaeis guineensis Jacq.) tissue cultures and seed-derived plants. Plant Cell Reports, 16: 884887.

SALVO-GARRIDO, H G; TRAVELLA, S; SCHWARZACHER, T; HARWOOD, W A and SNAPE, J W (2001). An efficient method for the physical mapping of transgene in barley using in situ hybridization. Genome, 44: 104-110.
SALVO-GARRIDO, H; TRAVELLA, S; BILHAM, L J; HARWOOD, W A and SNAPE, J W (2004). The distribution of transgene insertion sites in barley determined by physical and genetic mapping. Genetics, 167(3): 1371-1379.

SAMBANTHAMURTHI, R; SINGH, R; KADIR, A P G; ABDULLAH, M O and KUSHAIRI, A (2009). Opportunities for the oil palm via breeding and biotechnology. Breeding Plantation Tree Crops: Tropical Species (Mohan Jain, S and Priyadarshan, P M eds.). New York: Springer. p. 377-421.

SANFORD, J C; KLEIN, T M; WOLF, E D and ALLEN, N (1987). Delivery of substances into cells and tissues using a particle bombardment process. Particulate Sci. Tech., 5: 27-37.

SANTOS, A P; WEGEL, E; ALLEN, G C; THOMPSON, W F; STOGER, E; SHAW, P and ABRANCHES, R (2006). In situ methods to localize transgenes and transcripts in interphase nuclei: A tool for transgenic plant research. Plant Methods, 2: 18.

SCHWARZACHER, T; LEITCH, A R; BENNETT, M D and HESLOP-HARRISON, J S (1989). In situ localization of parental genomes in a wide hybrid. Ann Bot., 64: 315-324.

SENIOR, P J and DAWES, E A (1973). The regulation of poly- $\beta$-hydroxybutyrate metabolism in Azotobacter beijerinckii. Biochemistry J., 134: 225-238.

SINGH, R; ONG-ABDULLAH, M; LOW, E T L; MANAF, M A A; ROSLI, R; NOOKIAH, R; OOI, L C L; OOI, S E; CHAN, K L; HALIM, M A; AZIZI, N; NAGAPPAN, J; BACHER, B; LAKEY, N; SMITH, $S$ W; HE, D; HOGAN, M; BUDIMAN, M A; LEE, E K; DESALLE, R; KUDRNA, D; GOICOECHEA, J L; WING, R A; WILSON, R K; FULTON, R S; ORDWAY, J M; MARTIENSSEN, R A and SAMBANTHAMURTHI, R (2013). Oil palm genome sequence reveals divergence of interfertile species in old and new worlds. Nature, 500 (7462): 335-339.

STAM, M; DE BRUIN, R; KENTER, S; van der HOORN, R A L; VAN BLOKLAND, R; MOL, J N M and KOOTER, J M (1997). Post-transcriptional silencing of chalcone synthase in Petunia by inverted transgene repeats. Plant J., 1: 63-82.

SVITASHEV, S; ANANIEW, E; PAWLOWSKI, W P and SOMERS, D A (2000). Association of transgene integration sites with chromosome rearrangements in hexaploid oat. Theor. Appl. Genet., 100: 872-880.

SVITASHEV, S and SOMERS, D A (2002). Characterization of transgene loci in plants using 
FISH: A picture is worth a thousand words. Plant Cell Tissue and Organ Culture, 69: 205-214.

WILLIS, L B; YORK, G M; LESSARD, P L; JO, Y B; OMAR, R; MOHAMMAD ARIF, A M; PARK, C and SINSKEY, A J (2008). Reagents for generation and analysis of bioplastic producing plants. J. Oil Palm Res. Special Issue on Malaysia-MIT Biotechnology
Partnership Programme; 2 - Oil Palm Metabolic Engineering (July 2008): 56-68.

ZAMBRYSKI, P; JOSS, H; GENETELLO, C; LEEMANS, J.; VAN MONTAGU, $M$ and SCHELL, J (1983). Ti plasmid vector for the introduction of DNA into plant cells without alternation of their normal regeneration capacity. EMBO J., 2: 2143-2150.

\section{Early View}

Beginning October 2017, Early View is available in JOPR Microsite.

Articles which have been accepted for publication, edited and checked by authors are published online as Early View in Articles in Press section in the JOPR Microsite before the final online and print version of JOPR is published. Early View (also known as online first by other journals) articles although do not yet have page No. and volume/issue details but has been assigned to a Digital Object Identifier (DOI) No. for tracking and citations purposes. This is to accelerate the publication and dissemination of the latest research output.

To view all the articles currently available in Early View, visit http: / / jopr.mpob.gov.my / ?mycat=InPress 